\title{
Europe 1992: start of a migration boom?
}

Citation for published version (APA):

Heijke, J. A. M. (1990). Europe 1992: start of a migration boom? Researchcentrum voor Onderwijs en Arbeidsmarkt, Faculteit der Economische Wetenschappen. ROA Working Papers No. 5E https://doi.org/10.26481/umarow.199005E

Document status and date:

Published: 01/01/1990

DOI:

10.26481/umarow.199005E

Document Version:

Publisher's PDF, also known as Version of record

\section{Please check the document version of this publication:}

- A submitted manuscript is the version of the article upon submission and before peer-review. There can be important differences between the submitted version and the official published version of record.

People interested in the research are advised to contact the author for the final version of the publication, or visit the DOI to the publisher's website.

- The final author version and the galley proof are versions of the publication after peer review.

- The final published version features the final layout of the paper including the volume, issue and page numbers.

Link to publication

\footnotetext{
General rights rights.

- You may freely distribute the URL identifying the publication in the public portal. please follow below link for the End User Agreement:

www.umlib.nl/taverne-license

Take down policy

If you believe that this document breaches copyright please contact us at:

repository@maastrichtuniversity.nl

providing details and we will investigate your claim.
}

Copyright and moral rights for the publications made accessible in the public portal are retained by the authors and/or other copyright owners and it is a condition of accessing publications that users recognise and abide by the legal requirements associated with these

- Users may download and print one copy of any publication from the public portal for the purpose of private study or research.

- You may not further distribute the material or use it for any profit-making activity or commercial gain

If the publication is distributed under the terms of Article $25 \mathrm{fa}$ of the Dutch Copyright Act, indicated by the "Taverne" license above, 


\title{
EUROPE 1992: START OF A MIGRATION BOOM?*
}

ROA-W-1990/5E

\author{
J.A.M. Heijke**
}

* Paper presented to Prometheus-Europe for the Conference Universities and Companies: Recruitment at a European Level, Paris, 27-28 September 1990. The paper was originally published in Dutch in: H.A. van Stiphout et.al., Werkplaats Europa 1992, Organisation for Strategic Labour Market Research (OSA), no. V35, The Hague, 1990, pp. 189-200.

** With thanks to José Ie for collecting literature and statistical data, and to A.C.A. Elderson for translating the original Dutch text.

\section{RESEARCH CENTRE FOR EDUCATION AND LABOUR MARKET}

Faculty of Economics and Business Administration

Rijksuniversiteit Limburg

P.O. Box 616

6200 MD MAASTRICHT

The Netherlands

August 1990 
CONTENTS

Page

1. INTRODUCTION 1

2. DETERMINANTS OF MIGRATION 2

3. EUROPE AFTER 1992

4. FINAL REMARK 9

NOTES 


\section{INTRODUCTION}

The Treaty of Rome, concluded in 1957 by the six countries then making up the European Community, laid down the free movement of labour and the freedom of establishment as fundamental principles ${ }^{1}$. Free movement of labour implies, among other things, the abolishment of any nationality-based discrimination among workers from member states with reference to employment, wages, and other employment conditions. Workers were to have the right to accept jobs offered them, to move freely and stay in another state to practise a profession (article 48). Freedom of establishment enabled citizens of EC member states to settle independently, and set themselves up in business, in any other member state (article 52).

These stipulations seemed an important step towards completely unhampered mobility of labour among the countries of the European Community. However, practice appeared to be stronger than doctrine. For one thing, the agreements were subject to restrictions ${ }^{2}$. They did not apply, for instance, to government employment. Moreover, many persistent institutional obstacles make it difficult or unattractive for people to look for work in another member state. Far more importantly, however, international migration is dominated by economic and social factors, and evidently these factors have not given rise to any great expansion of the migration flows among the countries of the European Community.

In 1985, the European Commission submitted the so-called White Paper to the European Council, heralding a period in which the completion of the internal European market was to be tried for with new zeal. The White Paper contained a time chart for the removal of any material, technical and fiscal barriers still existing among the twelve current member states, so that at the latest by the end of 1992 a single large undivided market would be accomplished. That operation is expected to generate additional economic growth for the Community, hopefully to last into the next century. In the span of a few years, the extra growth of domestic product could run to between four and seven percentage points ${ }^{3}$.

The process of harmonisation and deregulation that has been set in motion is supposed to bring the competitive conditions for private enterprise better into line with the relative scarcity of production factors. The static and dynamic effects on the economy may vary much among countries. So, individual states may show either upward or downward deviations from the strong average impulse which European integration is expected to give to economic growth in the Community, deviations that will be reflected in the evolution of employment in member states. In individual member states, the evolution of employment might deviate in varying degrees from the autonomous development of the labour supply. An economy governed by classical laws, with labour a fully mobile production factor, would effortlessly smooth over any increasing discrepancy between the 
demand for and the supply of labour by additional migration of labour from countries with narrowing discrepancies on the labour market.

However, the labour market obeys the classical laws of supply and demand only to a limited degree, and the truly free movement of labour across the frontiers of member states seems still a long way off. But is that a reason for entirely dismissing the idea that differences in the economic effects of the single EC market could trigger off an international migration boom? In this paper we shall try to cull from the results of completed migration studies some leads towards an answer to that question.

No exhaustive review is intended of all that has been written about migration in the course of years. Rather we will focus on some aspects that seem relevant to the above question. The argument will be supported at various places with empirical data showing the significance of current labour migration among the countries of the Community.

\section{DETERMINANTS OF MIGRATION}

The economic theories of migration can be divided into micro and macro theories. Micro-economic migration theories reason from the point of view of an individual who, in a situation of uncertainty, has a choice of alternative spatial possibilities. Central to these theories are the migration motives of individuals. There are many such motives: people may migrate to improve their circumstances, but also to escape from political or religious pressure. Economic theories naturally leave political and religious factors aside. Because anyway these factors seem to be hardly relevant to internal migration within the European Community, they will also be left out of consideration in this paper.

Macro-economic migration theories do not centre around the individual migrant, but consider the entire economy. They argue that the reasons for migration are to be found in the regionally diverging prospects for economic development in relation with the availability of the production factors capital and labour. The geographic tension fields ensuing from such divergencies may give rise to flows of labour migrating from one region to another.

Micro-economic theories mostly try to continue the neo-classical tradition. In that vein of thought, the decision to migrate is understood to be comparable to a decision to invest in human capital ${ }^{4}$. For such a decision, future benefits are weighed off against the expenses incurred. With migration, the benefits are the sums by which the future income flow in the region of destination will exceed that in the present region of residence. Both flows are discounted by a rate expressing the evaluation of future income in respect of present income. Among the migration expenses are counted the costs involved in the removal and in the appointment of the new dwelling. Migration expenses need not be limited to the 
period in which migration occurs. The contacts with the region of origin, for instance, may endure for many years, and thus also the communication and travel costs involved in maintaining these contacts. To judge whether migration is profitable, its profits have to be reduced by the costs incurred, duly discounted. The theory predicts that people will migrate to those regions where the surplus of profits over costs is greatest.

The above represents the essence of micro-economic migration theory. However, there are other factors involved in the decision to migrate, factors that can be integrated in the theory ${ }^{5}$. One important factor is the existence of disequilibriums on the labour market. It means reckoning with unemployment, which reduces the migrants' chance of finding and keeping a job and hence the corresponding income.

The decision is also influenced by uncertainty and poor information. The higher educated tend to be better and more abundantly informed about possible migration alternatives than the lower skilled. That is why the higher skilled run less risk of an unsuccessful migration or an unwarranted decision not to migrate. A prominent source of information are relatives, acquaintances etc. already settled in the region of destination. To justify their own migration they will be inclined to draw rather a rosy picture of the opportunities in the country or region where they have settled, thus encouraging those left behind to come over as well.

A next factor - frequently referred to in migration studies - is the geographical distance. The longer the distance between two regions, the poorer will be the mutual information about the opportunities in the other region. Therefore, would-be migrants will be less inclined to migrate to a remote region. Geographical distance, however, affects the decision to migrate in more ways. A longer distance means higher expenses for removal and visits to friends and relations left behind. That may be another migration-restricting argument deriving from geographical distance.

Like geographical remoteness, social distance may be a bar to migration. The social distance felt to exist between inhabitants of different regions are mostly based on cultural differences. Differences in religion, language and style of living may therefore determine where would-be migrants would be happy to settle and where they would rather not ${ }^{6}$.

Age is a factor as well; as such it can be associated with the first factor, costs and benefits of migration. The theory predicts that the inclination to migrate declines with age, as the period for enjoying the net advantages of the change of region becomes shorter and shorter.

Finally, family circumstances can be mentioned as a factor influencing the decision to migrate. The reason is that an individual's decision to migrate becomes more complicated 
if the wishes and social positions of the other family members have to be taken into account. Particularly relevant is the question whether the partner is participating in the labour market, because in that case they both have to give up their position in the region of origin for uncertain prospects in a new region of settlement. Indeed, many migration studies conclude that the chance of migration is smaller for married people whose partner also has a job.

So much for some views following from the micro-economic approach to the migration problem. As observed at the beginning of this section, macro-economic theories of labour migration do not take the (motives of the) individual migrant as point of departure, but the overall economic situation in the different regions. The macro approach builds on to the neoclassical theory of international trade. This theory tries to explain international trade from differences in the relative scarcities of production factors. According to the so-called Heckscher-Ohlin theorem ${ }^{7}$, every country tends to specialise in the production of commodities which require inputs of production factors in proportions (the factor intensities) corresponding most nearly with the relative endowment with the same factors in that country. If in a country capital is amply available in relation to labour, that country will preferably produce capital-intensive commodities, and barter these commodities on the international market for labour-intensive products that are produced relatively cheaper elsewhwere.

An important assumption of this theory is that production factors are internationally immobile. Should production factors be fully mobile, then their international migration would level out international discrepancies in relative scarcity. As a result, there would be an end to international trade in commodities. Before that final situation is attained, a country where labour is becoming scarcer in relation to capital and thus more expensive, will be observed either to import more labour and export more capital, or to export more capital-intensive products.

The above line of thought leads to the conclusion that international trade and international migration are actually each other's substitutes, and that in the long run differences in the relative scarcities of production factors will disappear so that international trade becomes unnecessary. In the early 1970s, Rahimian examined for the then member states of the European Community whether the assumed substitution between commodity trade and labour migration could be proved true ${ }^{8}$. He found indeed a negative relation between labour migration within the Community and trade among member states.

\section{EUROPE AFTER 1992}

The theoretical conclusions from the previous section cannot simply be translated into forecasts of migration movements after the completion of one single European market. 
The effects of harmonisation and abolishment of trade-impeding regulations are hard to assess. The so-called Cecchini report ${ }^{9}$ mentions only a few broad effects of the completion of the internal market on the European Community as a whole. Estimating the consequences for the extent and direction of labour migration, makes it necessary to have more insight into the regional distribution of the positive and negative effects of the completion of the internal market on economic development compared with the autonomous development of the regional population. Failing knowledge on that score, this paper can do no more than give some indications of the possible evolution of migration. These indications will be derived from a closer study of some economic and demographic structural data of the twelve European member states in the light of the abovementioned theoretical conclusions about the factors underlying migration processes.

An indication of the significance of labour migration within the European Community is given by table 1 , which shows how many persons employed in each member state in 1987 had their origin in other member states, and how that quantity related to the total number of employed there. The figures found were relatively low: less than two per cent of the people employed in European Community had come from another member state. The percentages vary by only a few points among member states, only tiny Luxemburg being way out with a percentage of over 36 .

Table 1. Total number of employed in the EC member states, and number of employed from other member states, 1987

L A B O U R F O R C E

\begin{tabular}{lrcc} 
& $\begin{array}{l}\text { Employed } \\
\times 1000\end{array}$ & $\begin{array}{c}\text { Employed from } \\
\text { other member states } \\
\text { x 1000 }\end{array}$ & $\begin{array}{c}\text { Percentage of } \\
\text { foreign workers }\end{array}$ \\
\hline Belgium & 3,047 & 140.7 & 4.62 \\
Denmark & 2,392 & 12.4 & 0.52 \\
West Germany & 22,707 & 483.5 & 2.13 \\
Greece & 1,979 & 6.6 & 0.33 \\
Spain & 8,290 & -- & - \\
France & 18,240 & 589.6 & 3.23 \\
Ireland & 822 & 16.2 & 1.97 \\
Italy & 15,084 & -- & - \\
Luxemburg & 151 & 55.7 & 36.72 \\
The Netherlands & 4,791 & 86.1 & 1.80 \\
Portugal & 2,850 & 6.7 & 0.24 \\
United Kingdom & 22,127 & 398.2 & 1.80 \\
\hline
\end{tabular}

Source: Employment and Unemployment, Eurostat 1989 
Table 2. Employed from other member states in EC countries, 1981 and 1987

\begin{tabular}{lccc}
\hline & $1981^{\mathrm{a})}$ & 1987 & $1981-1987$ \\
& $\mathbf{x} 1.000$ & $\mathbf{x} 1.000$ & $\mathbf{x} 1.000$ \\
\hline Belgium & 145.6 & 140.7 & -4.9 \\
Denmark & 11.3 & 12.4 & 1.1 \\
West Germany & 696.0 & 483.5 & -212.5 \\
Greece & $6.9^{\mathrm{b})}$ & 6.6 & -0.3 \\
Spain & -- & -- & -- \\
France & $630.9^{\mathrm{b}}$ & 589.6 & -41.3 \\
Ireland & 15.1 & 16.2 & 1.1 \\
Italy & 4.0 & -- & -- \\
Luxemburg & $39.1^{\mathrm{d})}$ & 55.7 & 16.6 \\
The Netherlands & 84.1 & 86.1 & 2.0 \\
Portugal & -- & 6.7 & -- \\
United Kingdom & 406.0 & 398.2 & -7.8 \\
& & & \\
\hline
\end{tabular}
a) Inclusive of Spain and Portugal, joined later
b) 1982
c) 1979
d) Exclusive of Ireland, Denmark and Greece

Table 2 reproduces for the individual member states the numbers of employed persons originating from other member states, in 1981 and 1987. Apparently, the total number of European labour migrants dropped strongly in the intervening period. The explanation must probably be found in the migration processes in the remoter past. In the 1960 s and 1970s, there was a veritable migration wave of unskilled labour from the countries around the Mediterranean to North-West Europe. Italy, Greece, Spain and Portugal now members of the Community - were great suppliers of unskilled labour. However, industrial restructuring and renovation have made unskilled labour more and more redundant in North-West Europe. The economic recession put employment under even more pressure.

As a result, unemployment among migrants from Mediterranean countries rose to considerable heights. For Turks and Moroccans, the alternatives in their own countries were even worse, so that most of them have stayed on. For Italians, Greeks, Spaniards and Portuguese on the countrary, the prospects in their own countries were more favourable. The decline of internal labour migration in the European Community is indeed largely attributable to the return of the "guest worker generation" of the SouthEuropean member states. That last development may be an intimation of what progressively integrated EC economies may entail for labour migration among member states. 
From the theories exposed earlier, international migration of labour may be taken to spring mainly from different labour-market prospects (or, differently formulated: relative differences in labour scarcity) in the countries involved. Labour-market prospects (or scarcity differences) refer to the prevailing wage rates as well as the chances of work. A rough statistical indicator of the international differences on those scores may be the relation between GDP growth and demographic growth. Table 3 represents, for the 19801987 period, the growth percentages of GDP, population and GDP per head. By the simple line of thought adopted here, countries with high economic growth figures and slow demographic increase would exert potential immigration pressure. Countries with a slowly growing economy and a fast increasing population would on the other hand be potential emigration countries. To the former group of countries belonged in the period under discussion Denmark, Italy and the United Kingdom. Potential emigration countries would be Greece, France, Ireland, the Netherlands and Portugal. The position of the remaining countries is obscure as they combine either slow economic growth with slow demographic increase (Belgium and West Germany), or high economic growth figures with a fast increasing population (Spain and Luxemburg).

Table 3. Volume growth GDP and population growth in EC-countries, 1980-1987

\begin{tabular}{lccc}
\hline & Growth GDP & Growth population ${ }^{\text {a) }}$ & Growth per head \\
\hline Belgium & 7.6 & 0.3 & 7.3 \\
Denmark & 16.4 & 0.1 & 16.3 \\
West Germany & 10.5 & -0.7 & 11.2 \\
Greece & 7.7 & 3.8 & 3.9 \\
Spain & 16.7 & 4.3 & 12.4 \\
France & 12.2 & 3.5 & 8.7 \\
Ireland & 15.8 & 4.7 & 11.1 \\
Italy & 15.4 & 1.9 & 13.5 \\
Luxemburg & 23.1 & 2.2 & 20.9 \\
The Netherlands & 8.8 & 3.9 & 4.9 \\
Portugal & 14.6 & 4.3 & 10.3 \\
United Kingdom & 17.3 & 1.1 & 16.2 \\
European Community & 13.5 & 2.0 & 11.5 \\
\hline
\end{tabular}

a) Calculated as growth GDP minus growth GDP per head

Without profound analysis, there is no way of assessing how far the growth patterns described will continue through the 1990s and how the positive and negative results of the unification of the European market will be distributed among the member states. An important question is: will the growth figures converge or will some countries fall and 
remain out of step. The latter possibility might give a broad indication of increasing potentials for migration in the European Community.

The analysis suggested above far outranges this paper. Nor would it produce anything more than very vague indications. The fact is that a seemingly balanced macro picture of the labour market may disguise conflicting discrepancies in terms of qualitative and spatial sub-markets, entailing as many opposed migration movements.

The first objective of the completion of the European market is to obtain equal competitive conditions among member states, and facilitate international trade. The stimulus thus exerted on the economic growth of the member states will be attended by an accelerated increase of internal trade within the Community. By migration theory, based on the theory of international trade, that should entail less labour migration. Perhaps that effect was already discernable in the past period; the increased trade among member states may have contributed to the drop in labour migration then observed. By joining the EC, Spain and Portugal may have traded in their position of suppliers of labour for that of exporters of commodities produced with a relatively high intensity of labour to the late immigration countries, now co-members, in Europe.

Other developments within Europe, stimulated more or less by the completion of the internal market, are also having an effect on the international mobility of labour. Such developments influence the direction of mobility and particularly its total level. The reason is that they are occurring very much everywhere in the Community, but not everywhere to the same degree.

The first development to be named is the reduction of travel distances by the expansion of air traffic and the intensification and acceleration of international rail transport. That evolution stimulates mobility directly, and also creates new prospects for mobility by widening the scale of international passenger transport. The same development also means that within Europe, residential and employment regions may drift further apart. As a result, international labour migration will more and more take the form of daily or weekly long-distance commuting, which makes for the optimum combination of an attractive living environment and favourable working conditions.

Another development concerns the social distances within the Community. These distances, and the bond people feel with the region where they have grown up, form serious impediments to migration. In a European Community with a fully integrated market, the exchange of information will intensify and linguistic barriers gradually be overcome. The Community as a whole will possible acquire more of an identity and thus grow on the minds of its citizens. Such developments might reduce the social distances and thus open the way to greater international mobility. A self-reinforcing effect may be 
expected, because larger migration flows will entail a more intensive exchange of information, which in turn may help towards removing any remaining barriers to migration.

In the theoretical section, the significance of the educational level for labour migration has been pointed out. The better and richer information

sources of the higher skilled and their favourable effects on geographical labour mobility have been referred to. No mention was made of the fact that schooling tends to make labour more specific. Therefore, to find a suitable occupation, the higher-skilled have to orient themselves to a geographically more extensive labour market. Thus, the rising level of education of the European populace will stimulate international labour migration along that avenue as well.

Another relevant development is the increasing participation of women in the labour market. It is a phenomenon common to all European countries. On the one hand it will lead, as pointed out already, to a more complex migration decision as far as married women are concerned; on the other it will enlarge the job-seeking labour force, thus generating, ceteris paribus, an increased urge to migrate. Quite possibly, increased participation of (married) women, along with the improved travel possibilities already mentioned, will lead to increased international commuting rather than migration.

From the above somewhat speculative arguments may be inferred that the completion of the internal European market will not be attended by any spectacular "migration boom". Admittedly, the declining tendency of the past is expected to reverse upward. Presumably, the future development of migration will be marked first and foremost by increased gross flows among member states, the inflows and outflows more or less balancing each other in the long view. At any rate, a dramatic - one-sense - migration flow of labour from or to one of the member states is improbable.

\section{FINAL REMARK}

At the end of this paper the fact must be emphasised that only internal migration within the European Community has been under discussion. The situation with regard to the migration of persons between the European Community and the surrounding parts of Europe, Asia and Africa is entirely different, but its treatment would be beyond the range of this paper. Suffice it to point out some tendencies that may place the significance of internal migration in quite a different perspective. Demographic growth in the European member states is observed to be slow and even declining in some cases. In the less developed African and Asian countries, on the contrary, the population is growing fast, frequently outpacing the increase of subsistence opportunities. As the international exchange of information intensifies and opportunities for travelling improve, 
the continuation of that trend may generate in those countries an increased potential for migration to the prosperous parts of Europe, where perhaps in the long run ways and means will have to be found to keep the labour force at par. However, as explained above, the problems associated with developments on the "outer frontiers" of the European Community are not the concern of this paper ${ }^{10}$.

\section{NOTES}

1. See, for instance, Commission of the European Communities, The Social Dimension of the Internal Market, Social Europe, Luxembourg, 1988.

2. See, among others, Jean-Claude Séche, $A$ guide to working in Europe without frontiers, Commission of the European Communities, Document, Luxembourg, 1988.

3. Paolo Cecchini, The European challenge 1992, the benefits of the single market, Brussels, 1988.

4. Compare the synthesis by M.J. Greenwood, Research on Internal Migration in the United States: A Survey, Journal of Economic Literature, Volume 13, 1975, pp. 397443.

5. Compare, for a concise survey: J.A.M. Heijke, Internationale migratie en bevolkingsstructuur, in: Demografische veranderingen en economische ontwikkelingen, Preadviezen van de Koninklijke Vereniging voor de Staathuishoudkunde, 1987, Leyden/Antwerp, pp. 125-156.

6. Compare for the influence of cultural differences on international migration: Hans Heijke, The Labour Market Position of Migrants in Selected European Receiving Countries, in: The Future of Migration, OECD, Paris, 1987, pp. 170-209, and Willem Molle and Aad van Mourik, International Movements of Labour under Conditions of Economic Integration: The Case of Western Europe, in: Journal of Common Labour Market Studies, Volume XXVI, Nr. 3, March 1988, pp. 317-342.

7. B. Ohlin, Interregional and international trade, 1933.

8. Nasrollah Rahimian, Trade and Labour Migration in the E.E.C., $\mathrm{PhD}$, Indiana University, 1975.

9. Paolo Cecchini, loc.cit.

10. For some indications, compare Heijke, loc.cit. 1987, pp. 148ff. 